\title{
CHILDREN'S RESPONSE TO THE UTTERANCES OF THEIR PARENTS' NEGATION: COMMUNITIES IN KARTASURA
}

\author{
Kurniawan \\ Doctoral Student in Humanities, Faculty of Cultural Sciences \\ Universitas Gadjah Mada, Yogyakarta, Indonesia \\ E-mail: kurniawan_kec@yahoo.com
}

Received: 24 Maret 2020

Accepted: 06 May 2020

\begin{abstract}
The act of obeying parents' right to control them or refusing the directives by challenging their parents' authority are two preferences children may opt for. This present investigation concerns to what extend children respond upon hearing negative utterances aimed for them. This qualitative research applies a theory of speech acts proposed by Austin (1962) to analyze data classified as negation utterances. Four families living at the Kartasura become this research data source. To collect the data, the researcher implements direct observation by recording audio and taking notes on the parents and their children's interaction within a period of approximately an hour. The result of the study implies that mostly Kartasura children do what their parents tell them to do, while few data indicate children's refusal of parents' negations. One reason is due to the cultural value held tightly and bequeathed by Javanese through a number of centuries that is the act to honor and obey parents' directives. To sum up, the implementation of negative utterances in the parenting world is not prohibited; however, parents must keep in mind the use of proper portion.
\end{abstract}

Keywords: speech act, negation utterances, children responses

\section{Introduction}

Directive claims an entitlement to control the hearer's actions since it involves authority, social status, as well as cultural dimension (Cutting, 2002 and Kent, 2012). This speech act category is one of the parenting language styles mostly occurring in family communication. Erlanti, et al. (2016) agree that parents are required to own competency and ability with the result that their speeches can be categorized as right parenting communication patterns. What parents speak determines and ultimately affects the language development and mental health of children. Furthermore, children are offered two choices upon facing to directions uttered by parents; they obey and accept their parents' right to control them or reject the directives by challenging their parents' authority.

What will children do when a parent tells them what to do? One impulse that every parent must have is to prevent, warn, and even forbid their children from not doing something. This action is considered necessary as parents assume that they have better comprehension on what is good and not rather than their children. One reflection can be seen from one phenomenon. The directive words "Don't eat by your left. Use your right hand." is an example of parental directive intended to negate and warn children. This 
negation is based on Indonesian cultural value held tight by parents' beliefs that the use of right hand is a must while people are at mealtimes. Rijal (2015) highlights there will be parties who are more in charge of the communication process, in this case parents. This dominance occurs because parents have a greater interest in the growth and development of children.

Children development phase supposes parents to reprimand their children with various types of utterances. The fact says negation speech acts is one of the most frequently utterances used. Negation means negative words such as don't turn around or don't cry. The exploitation of that negation's speech will have a psychological impact on children inasmuch as subconscious mind is difficult to process and accept the utterances involving negative meaning. The words, as the result, captured by children's subconscious mind are turn around and cry. What will happen then? that children will turn around and keep crying. One of the phenomenal thoughts of Freud (1980)-a father of Austrian psychoanalysis - writes in his book that people subconscious mind is only able to recognize positive words, and indeed it will be in adversity situation to grasp negative words. Nevertheless, the use of negation utterances in practice is much more common than positive utterances.

The objective of the study is to explore children's response to utterances involving parents' negation in parental environment. It will be seen how children act, whether they do what their parents tell to do or refuse their parents' words by giving arguments or keep doing what they want to do. This is considered a crucial to investigate that case since negation utterances spoken by parents to their children hold significant impact toward children's psychology as well as language development. Children whose age are 2 to 5 year will be the object of this present study. An approach proposed by Austin (1962) is adopted in this paper in order to achieve research objective. The researcher analyses the data by collecting negation words uttered by parents and investigates how children respond to those utterances.

By focusing on children's response of parental negation, it is believed to fill the research gap and contribute an understanding how negation utterances are able to influence the action as well as language development of children under 5 years old. Afterward this study is expected to be useful in developing and expanding insight regarding the urgency and role of language in connection with pragmatics and parenting field. In doing so, comprehending what interlocutor means in the phase of children's language acquisition is essential for the development of children communicative abilities. Children aged 2 to 5 years is a period where they experience the stages of learning and gaining language. Parents, as the consequence, need to pay much attention toward the lexical choices used to direct their children as they will automatically copy what their parents say.

\section{Literature Review}

\section{Parents' Negation}

According to Austin (1962) and Yule (1996) directive speech acts mean speech uttered by speakers who have intended purpose that the interlocutors take action in accordance with the speakers mean. Negation is a kind of this speech act. Negation is defined as an act of expression that denies and refuse the speeches uttered by interlocutors. One example of the negation implementation is negative words usage. In bahasa Indonesia, it is well-known the word "tidak", "bukan", "jangan", "dilarang", and so forth. This argument is not in line with the thought of Diharti (2013) and Mappau (2017) who state that negation markers does not only deal with the negative word "no" or "not", yet it can also relate to the 
meaning of rejection, negation, as well as denial utterances. As penned by Givon (1979) and Lyons (2013) say that the main function of negation is to refute utterances or actions considered to infringe the rules and norms. This language style is commonly utilized by speakers to designate a contrast or prohibit their interlocutors to do something.

Discussing negation utterances aimed at disallowing children will automatically get in touch with mind. Freud (1980) assumes that humans consist of two consciousnesses, that is, $88 \%$ influenced by the subconscious mind, while the conscious mind, obtained from knowledge background, only possesses a $12 \%$ percentage. Then a question raises, does it also occur in children's life? The fact portrays that the unconscious dominates children mind since they utilize it upon communicating and interacting with others. Zainurrahman (2016) opines that unconscious mind has a large portion in affecting behavior of every human compared to individual conscious mind as it becomes the basis of every movement.

Conscious mind is the initial process of human mind to receive, analyze, and think about information gained. This is a thought process that someone does consciously and enables to be controlled. For instance, people desire to determine which meal is worth to be ordered in a restaurant based on their conscious logic. In another side, the subconscious mind is a dimension where all information is stored into mind programs, such as beliefs, values, and skills. This can be considered as a virtual storage where the data are accessed and run by humans for their daily lives. For instance, someone will automatically find water to drink when thirst surges. (Freud, 1980; Rijal, 2015; Zainurrahman, 2016)

\section{Previous Studies}

Research on the topic of children's response to directive speech acts has been carried out in last decades. A number of studies provides more information regarding children's comprehending of direct and indirect directives. The result indicates that indirect requests are substantially different and more complex than direct requests due to the fact that children have not had a competency to catch implicit message of utterances (Elrod, 2012 and Kent, 2012). On the other hand, Arcidiacono and Bova (2015) have ever undergone a research in family discourse. Their study examines parental speech acts of control, whether "to order" and "to warn" their children at mealtime conversation at the dinner table and how the children respond towards parents' directives. It is discovered that children aged 6-9 years use arguments to refuse and refute the parental eat-directives.

In addition to children response investigation, a group of studies concerns on discovering on how children respond to their parents' directive. This study is about the competence of early childhood in perceiving and producing directive speech acts whether those are spoken directly or indirectly. The result shows that children's ability to perceive speech acts are manifested in verbal responses and actions concerning the illocutionary act (Kusumaningrum, 2017; Ocktarani, 2017; Wahyuniarti, 2017; Wulandari, 2018). Those previous studies are still oriented towards the analysis of speech acts in general, without specifying them. They are not dealing with particular speech acts aspect like prohibition utterances consisting negation words.

\section{Research Method}

This study is classified as qualitative since it deals with examining how children respond to their parents' negation utterances. Aspects to be described are in the form of utterances done by children, therefore, this is categorized as a descriptive study (Creswell, 2012; Denzin \& Lincoln, 2005). It involves the utterances of parents and children as the 
participant of study to find new insights related to speech acts in parenting field. This data source was located in family's environment living at Kartasura city. The fundamental reason for choosing this location was due to community diversity, including highly educated families and owning an established economy dominated by migrants; and the other one was family whose educational and economical ownership was not classified as good. The utterances were investigated by pragmatics theory proposed by Austin (1962) used as a tool for analyzing the research data. It focused on directive speech acts that contained negation utterances to warn and prohibit hearer not to do something.

To collect the data, the researcher implements direct observation by recording audio and taking notes concerning conversation undergone by parents and their children. Both participants were set to have a verbal interaction within a period of approximately an hour which took place at public market and playground. After the data had been gathered, they were analyzed though these procedures: the recording was transcripted according to Jefferson's transcription conventions (2004) and determined which data belong to negation utterances. Finally, the researcher looked into in depth how children responded to those words by exploiting speech act approach. The analysis was primarily concerned on children responses toward parents' negation words recorded specifically to this present project.

\section{Result and Discussion}

\subsection{Research Result}

The result of this study was carried out on four families living at Kartasura. The researcher detected 38 data categorized as negation utterances and children's responses to utterances addressed. This data were taken in various diverse locations, including parks, supermarkets, and children's playgrounds. Here are the data in details and the analysis:

\begin{tabular}{cccc}
\hline No & Parents' Negation & Frequency & Percentage \\
\hline 1 & Fathers' utterances & 20 & 50 \\
2 & Mothers' utterances & 20 & 50 \\
& Total & 40 & 100 \\
\hline
\end{tabular}

Datum: 5/father's

Ayah : Jangan banyak-banyak ya. (don't eat too much)

Anak : Satu aja. (one?)

Ayah : lya satu aja. Tadi kan sudah makan jajan. Jadi ini jangan banyak- banyak ya. Nanti giginya?

(yeah, one is enough. You have eaten snack. So, don't eat this too much. Otherwise your teeth......?

Anak : Kropos

(Cavity)

Situational context: A father forbids his son from eating large portions because he ate Oreo snack a couple of minutes ago

The datum portrays that a farther did not allow his child to eat much. The lexeme "jangan (do not)" at "jangan banyak-banyak ya" utterance is a negation marker exploited by a father in the application of speech act. That prohibition was spoken with the aim that children would not consume sugary meals. Otherwise his teeth will be increasingly eroded. 
As the response, he nodded his head while saying that he only consumed a packet of food upon listening to his father's words. This reaction was as the same as what the father expected.

Datum: 10/mother's

$$
\begin{aligned}
\text { Anak } & \text { : tak kasih daun ya } \\
\text { (can I feed with leaves?) } & \text { : jangaaannn } \\
\text { Ibu } & \text { (No...!) } \\
\text { Anak } & \text { : la emangnya kenapa? } \\
& \text { (what's wrong) }
\end{aligned}
$$

Situational context: A child asked her mother whether she could feed a deer with a leaf, and the mother did not allow her.

Datum 2 above is a reflection of the phenomenon of a mother's effort to warn her daughter that feeding deer with a leaf was disallowed. That prohibition utterance was conveyed as the leaves, in mother's belief, held by the child were too dirty so they were not worth for animal consumption. This negation utterance realized by the word "jangan" is frequently utilized by the Indonesians to inhibit speech partners. On hearing that negation, the child then did not immediately follow the instruction. However, a question raised on her mind why it was not allowed. The mother answered in detail that the leaves on her daughter hand are not deer food, or might be contaminated by mud.

Datum: 13/mother's

Anak : Aku sekarang udah ganti SGM

(I've changed to SGM mom)

Ibu : nanti perutnya nggak kuat tho

(your stomach will hurt)

Anak : halahhh. SGM ma...

(Come on mom, SGM yeah?)

Situational context: Mother forbids her son from buying milk labelled SGM because he had ever got stomach-ache after consuming this product

One of the negation utterances of commonly exploited by the Indonesians is lexeme "nggak" or known in English as "no / not". It can be seen from a piece of conversation between mother and son in a supermarket. The son requested his mother to buy milk

\begin{tabular}{|c|c|}
\hline Ayah & : eh jangan gitu nanti jatoh \\
\hline & (Don't do that, or you go into a skid) \\
\hline Anak & $\begin{array}{l}\text { : tetap berlarian } \\
\text { (keep running) }\end{array}$ \\
\hline Ayah & $\begin{array}{l}\text { : Ssssttttt dek! } \\
\text { (Ssssttttt son) }\end{array}$ \\
\hline Anak & $\begin{array}{l}\text { : berhenti berlarian } \\
\text { (stop running) }\end{array}$ \\
\hline
\end{tabular}
labelled SGM. The mother did not grant the son in consideration that her son had experienced stomach problem due to this milk. As the effect of mother's negation, he replied by saying "SGM ma...!" in response to persuading mother. He was not in line with his mother's suggestion.

Datum: 15/father's 
Generally speaking, children served two choices upon hearing to parents' directions; they obey to be controlled or reject the directives by challenging their parents' authority. The above example is the condition where a son refused parental speech aimed at telling him to stop running. He kept running even his father told him what to do. Subsequently, the father uttered the word "Ssssttttt dek!" with high as well as loud pitch to catch his son's attention. The son immediately stopped running instead.

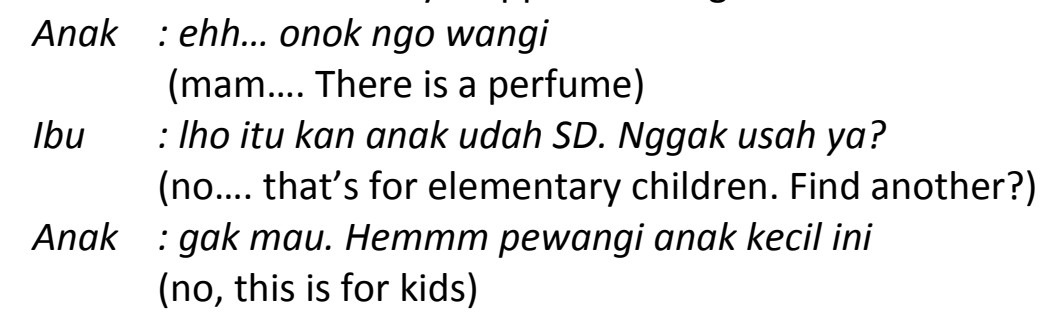

Situational context: The child points at and takes a perfume, but the mother forbids him to take that perfume since it is made for a child older than his age, while he is still a toddler.

Child's response is marked by the words "gak mau. Hemmm pewangi anak kecil ini" which implies that the child disagrees with his mother's assumption. Mother- after reading the information written on the packaging-opined that the perfume was intended for children over the age of 7 , while her son was only 5 years old. However, the child denied that opinion by arguing this perfume was able to be put on by a child at his age. He insisted on owning the item.

\subsection{Discussion}

The analysis of the data presented in previous statement has revealed that compliance is a response to actions that often appear (but not always) to comply with parental directives in speech negation. Children whose age under 5 years old have not yet gain capability to express their wishes with their language. This incompetence unconsciously makes mostly children, in this data, obey parents' utterances involving prohibition. Nonetheless, researchers found a couple of cases ( 9 of 40 data) indicating children's noncompliance against negation utterances. The analysis highlights that refusal speech acts is difficult to be undergone by toddlers. When children as hearer expresses rejection, their action can lead to increased control efforts by parents (speaker) to show power legitimation they have. Parents will try to get children to take action as what they expect. Then there will be obedience from the authority built by parents in parenting.

This research has an opposite result with the findings in the study conducted by Arcidiacono \& Bova (2015). They highlighted children aged 6-9 years use arguments to refuse and refute the parental eat-directives. Children will propose an argument concerning parents' commands. It portrays that they express what is believed by words. On the other hand, children aged 2-5 years on this study mostly do what their parents tell them to do. Only few actions indicate disapproval of parent's authority. Kent (2012) took into account to what would children do when their parents told them what to do. His study assumes that it is inconvenient and tough for children to refuse parental directive speech acts. They, therefore, obey and choose to ratify parents' control attempt. They undergo actions as what their parents expect them to do.

The result of this present study is on the contrary to theory proposed by Freud (1980) as the founder of psychoanalysis concerning human consciousnesses. He declare that children subconscious mind is not capable to accept and difficult to process information in 
sentences or utterances containing negative words. Subconscious mind is only able to recognize positive words, based on his argumentation. This research finding brings to light an interesting insight on children language competences. They still take part in parents' directions though these are classified as negation speeches. This present investigation provides us more information regarding children's responses to negation utterances. It challenges the view that processing negative words to prohibit children will be declined.

The conversational exchanges between parents and children have been proposed as examples of Javanese cultural values that have been instilled in children's mind from birth. The value held tightly and bequeathed through various centuries is the act to honor and obey commands, advice, and prohibitions given by parents. Infallible power attached in parents' authority cause them entitled to regulate and children's development. Parents get children to follow their directions as well as respect (Irawan, Prasetyo, \& Arsi, 2016; Rochayanti, Pujiastuti, \& Warsiki, 2012). This pattern is familiar with the term Authoritative Parenting. Parents take full control and dominant influence in shaping children character from an early age. As a result, they set rules for children to carry out, such negation utterances to prohibit (Santrock: 2011) in his book entitled Child Development for detail information).

On the other side, there are three patterns portraying children non-compliance in responding to speech acts of their parents' negations. Firstly, children totally neglect to what parents tell them not to do. They are not willing to lend an ear to parents' directives. Second pattern is the act of raising interrogatory. Children will propose question (s) what cause them not to be afforded an opportunity undergoing a certain action. In this case, parents have to provide answers to convince that their actions should not be carried out. Last but not least, counter-arguments are advanced by children as the sole indicator to support and justify their resistance to parents' negations. They pronounce opinions due to their disagreements toward interlocutors' point of views.

Researchers give credence that the implementation of negative utterances is not prohibited, however parents must keep in mind the proper portion level of this utterance usage. Rijal (2015) asserts Linguistic encodings consisting negative words must be limited since human right brain memory of children is not capable to store negative encodings. Right brain in early childhood is only adequate to respond certain words that have positive meaning. In addition to right brain performance, Al-Qur'an - the holy script uses as a guide for Muslims' life guidelines-containing the word " $y$ " which is defined as "don't" 358 times (Ahmadi \& Shobahiya, 2017; Hasan \& Sunardi, 2018). This indicates parents may utter negation words as long as they are still within the scope to instill the values of the Aqeedah, Morals and Shari'ah towards children.

\section{Conclusion}

The speech acts of parental controls have been shown repeatedly based on this finding. This research result indicates that compliance is an action response which mostly arises (but not always) as a result of parental direction in case of speech negation. Incapability to express their wills through language and Javanese cultural values instilled in their mind causes children to honor and comply with parents' directives. It is discovered three varieties, how children do non-compliance; not lending an ear to parents' utterances, proposing interrogatory with some questions, as well as stating counter-arguments toward parent's negation. 
Parents need to underline lessons learned from this research. The implementation of negative utterances is not prohibited; however, parents must keep in mind the proper portion level of this utterance usage. It should be taken into account when negation utterances should be applied and vice versa. It remains to be seen how far the patterns of parental directives affect children's response in other contexts. It is interesting to follow up research on conversational exchange in parenting field involving gender and ethnic. Gender differences affect the response patterns that emerge from the children's side.

\section{References}

Ahmadi, A. Z., \& Shobahiya, M. (2017). Penggunaan Kata "У”" Bermakna "Jangan" dalam AlQur'an (Perspektif Pendidikan Islam). Suhuf, 29(2), 125-138. Retrieved from https://docplayer.info/82643102-Penggunaan-kata-l-bermakna-jangan-dalam-al-quran-perspektif-pendidikan-islam.html

Arcidiacono, F., \& Bova, A. (2015). Activity-Bound and Activity-Unbound Arguments in Response to Parental Eat-Directives at Mealtimes: Differences and Similarities in Children of 3-5 and 6-9 Years Old. Learning, Culture and Social Interaction, 6, 40-55. https://doi.org/10.1016/j.lcsi.2015.03.002

Austin, J. L. (1962). How to Do Things with Words. London: Oxford University Press. Retrieved from

https://libgen.is/book/index.php?md5=5734CC8D854D6B8D8ED46445F1C2A9CB

Creswell, J. W. (2012). Educational Research: Planning, Conducting, and Evaluating Quantitative and Qualitative Research. Boston: Pearson Education, Inc.

Cutting, J. (2002). Pragmatics and Discourse. New York: Routledge. Retrieved from http://93.174.95.29/_ads/3CAA135D9BD5592F89E828E007DD2A4A

Denzin, N. K., \& Lincoln, Y. S. (2005). The SAGE Handbook of Qualitative Research (Third Edit). California: Sage Publications, Inc. Retrieved from http://93.174.95.29/_ads/FAD5A9278C21C1C2DAB32963433DC2C8

Diharti, S. (2013). Penggunaan Kalimat Negatif dalam Bahasa Mongondow Dialek Mongondow. Widyariset, 16(1), 131-138. Retrieved from http://widyariset.pusbindiklat.lipi.go.id/index.php/widyariset/article/download/101/ pdf

Elrod, M. M. (2012). Young Children's Responses to Direct and Indirect Directives. The Journal of Genetic Psychology: Research and Theory on Human Development, 143(2), 217-227. https://doi.org/10.1080/00221325.1983.10533555

Erlanti, M. S., Mulyana, N., \& Wibowo, H. (2016). Teknik Parenting Dan Pengasuhan Anak Studi Deskriptif Penerapan Teknik Parenting Di Rumah Parenting Yayasan Cahaya Insan Pratama Bandung. Prosiding Penelitian Dan Pengabdian Kepada Masyarakat, 3(2), 155-291. https://doi.org/10.24198/jppm.v3i2.13686

Freud, S. (1980). The Interpretation of Dreams. New York: Avon. Retrieved from http://93.174.95.29/_ads/51D0C3639EC6F33F5504460AF7169898

Givon, T. (1979). On Understanding Grammar. Orlando: Academic Press, Inc. https://doi.org/10.2307/2107340

Hasan, A., \& Sunardi. (2018). Kontekstualisasi Makna У (Jangan) dalam Q.S. Luqman/31:13 dalam Mendidik Anak. Raushan Fikr, 7(1), 65-74. https://doi.org/10.24090/JIMRF.V7I2.2525

Irawan, M., Prasetyo, K. B., \& Arsi, A. A. (2016). Pergeseran Nilai Orangtua di Kalangan Masyarakat Jawa (Studi Pada Lansia yang Tinggal di Panti Wredha Dharma Bhakti 
Surakarta). Solidarity: Journal of Education, Society and Culture, 5(2), 177-188. Retrieved from https://journal.unnes.ac.id/sju/index.php/solidarity/article/view/14502

Jefferson, G. (2004). A sketch of some orderly aspects ofoverlap in natural conversation. In G. H. Lerner (Ed.), Conversation Analysis : Studies from the First Generation (p. 43). Amsterdam: John Benjamin Publishing Company. Retrieved from http://93.174.95.29/main/E067B17ABD5867397EC23F8D40967E71

Kent, A. (2012). Responding to directives: What can children do when a parent tells them what to do? Sociological Studies of Children and Youth, 15, 57-84. https://doi.org/10.1108/S1537-4661(2012)0000015007

Kusumaningrum, A. S. (2017). Comparative Study on Directive Speech Acts and Its Response between Indonesian and English Children (Muhammadiyah University of Purwokerto). Retrieved from http://repository.ump.ac.id/5132/

Lyons, J. (2013). Linguistic Semantics: An Introduction. New York: Cambridge University Press. https://doi.org/10.4324/9781315044644

Mappau, R. (2017). Konstituen Pengungkap Negasi dalam Bahasa Makassar Dialek Lakiung dan Turatea. Sawerigading, 23(1), 127-137. https://doi.org/http://dx.doi.org/10.26499/sawer.v23i1.181

Ocktarani, Y. M. (2017). Kemampuan reseptif Anak Usia Tiga Tahun terhadap Tindak tutur Direktif. Lingua, 13(2), 182-192. Retrieved from https://journal.unnes.ac.id/nju/index.php/lingua/article/view/11969

Rijal, S. (2015). Hipnolinguistik : Bahasa Alam Bawah Sadar. Jurnal Pendidikan Progresif, 5(2), 190-198.

Retrieved

from http://jurnal.fkip.unila.ac.id/index.php/jpp/article/view/14902/0

Rochayanti, C., Pujiastuti, E. E., \& Warsiki, A. Y. N. (2012). Sosialisasi Budaya Lokal dalam Keluarga Jawa. Jurnal IImu Komunikasi, 10(3), 308-320. Retrieved from http://jurnal.upnyk.ac.id/index.php/komunikasi/article/viewFile/44/48

Santrock, J. W. (2011). Child Development (Thirteenth). New York: McGraw - Hill Companies, Inc. Retrieved from https://libgen.is/book/index.php?md5=854F44F24B84A9958B331716565B00F6

Wahyuniarti, F. R. (2017). Pemerolehan Makna Pragmatis Dalam Tindak Tutur Direktif pada $\begin{array}{lllll}\text { Anak Usia } 5 & \text { Tahun. } & \text { Sastranesia, }\end{array}$ https://doi.org/https://doi.org/10.32682/sastranesia.v5i4.660

Wulandari, S. (2018). Respons Verbal Anak Usia 5-6 Tahun pada Tindak Tutur Direktif Orang $\begin{array}{llll}\text { Tua. Madah: Jurnal Bahasa Dan Sastra, } & 85 .\end{array}$ https://doi.org/10.31503/madah.v9i1.708

Yule, G. (1996). Pragmatics. New York: Oxford University Press. Retrieved from http://93.174.95.29/_ads/1CBAB90E792B235D81119117EBB7C9B4

Zainurrahman. (2016). Peran Pikiran Bawah Sadar (Subconscious Mind) dalam Proses Menulis dan Pembelajaran Naratif. Gramatika: Jurnal Ilmiah Kebahasaan Dan Kesastraan, 4(1), 49-58. https://doi.org/10.31813/gramatika/4.1.2016.47.49--58 